\title{
HUBUNGAN STATUS GIZI DENGAN PERKEMBANGAN ANAK USIA 1 - 5 TAHUN DI POSYANDU DESA SIRNOBOYO KABUPATEN WONOGIRI
}

\author{
Ratna Indriati ${ }^{1}$, Yurika Kristi M. ${ }^{2}$
}

\begin{abstract}
Background Child under five years of age is the period of life that are very important and need serious attention. During this process of growth and development very rapidly. One of the important factors that affect child development is a nutritional factor

The purpose of this study was to determine the relationship of nutrition status with the development of children aged 1-5 years in Sirnoboyo village of Posyandu Wonogiri Regency

Method Correlation research design with cross sectional approach . The subject of research is the 35 children aged 1-5 years with his mother in Sirnoboyo village of posyandu Wonogiri Regency with technique purposive sampling. Data obtained by doing observation to know nutritional status and child development. The data obtained are then analyzed by chi square test with $p=0.05$

Results showed the child with good nutritional status of as many as 25 children $(71,43 \%)$, nutritional status less as much as 9 child $(25.71 \%)$ and better nutritional status as much as 1 child $(2.86 \%)$ while the children with normal development of as many as 24 children (68,57\%) and a total of 11 children of questionable developments $(31,43 \%)$. The results of the analysis using the chisquare test $p=0.006$ obtained so that the value of $p<0.05$, which means that Ho is rejected and $\mathrm{Ha}$ accepted.

The Conclusion of the research was there is relationship of the nutritional status with the development of children aged 1-5 years in Sirnoboyo village of posyandu Wonogiri Regency
\end{abstract}

Keywords : Nutritional Status, Development

\section{PENDAHULUAN}

Gizi adalah suatu proses penggunaan makanan yang dikonsumsi secara normal oleh suatu organisme melalui proses digesti, absorbsi, transportasi, penyimpanan, metabolisme dan pengeluaran zat-zat yang tidak digunakan untuk mempertahankan kehidupan, pertumbuhan, dan fungsi normal dari organ-organ, serta menghasilkan energi. (Proverawati dan Wati, 2011)

Kandungan gizi pada makanan yang dikonsumsi setiap hari menentukan status gizi anak. Status gizi yang baik mampu meningkatkan daya tahan tubuh yang baik pula, sebaliknya status gizi yang buruk memudahkan timbulnya penyakit. Oleh karena itu makan bukan hanya kebutuhan fisik utama semata namun juga diperlukan sebagai faktor penunjang pertumbuhan dan perkembangan, sedangkan pertumbuhan itu merupakan langkah awal bagi perkembangan. (Salsabila, 2010)

Masa balita merupakan masa kehidupan yang sangat penting dan perlu perhatian yang serius. Pada masa ini berlangsung proses tumbuh kembang yang sangat pesat yaitu 
pertumbuhan fisik dan perkembangan psikomotorik, mental dan sosial. Salah satu faktor penting yang mempengaruhi tumbuh kembang anak adalah faktor gizi. Kekurangan gizi pada anak akan berdampak pada keterbatasan pertumbuhan, rentan terhadap infeksi, dan akhirnya dapat menghambat perkembangan anak. Sehingga anak perlu memperoleh gizi dari makanan sehari - hari dalam jumlah yang tepat dan kualitas baik. (Muaris, 2006)

Kurangnya gizi pada tingkat ringan atau sedang masih belum menunjukkan gejala yang abnormal, anak masih bisa beraktivitas, bermain dan sebagainya, tetapi bila diamati dengan seksama badannya mulai kurus dan staminanya mulai menurun. Disamping itu kondisi kurang gizi yang terjadi pada balita, khususnya pada masa golden period perkembangan otak (0-3 tahun), otak tidak dapat berkembang sebagaimana anak yang sehat, dan kondisi ini akan mempengaruhi perkembangan anak. Bila anak mampu tercukupi status gizinya maka proses perkembangannya pun baik. Karena anak adalah potensi penerus cita-cita bangsa, jika anak dipupuk dan dipelihara dengan baik, maka anak akan berkembang dengan baik pula sesuai dengan keinginan dan harapan. (Salsabila, 2010)

Perkembangan merupakan perubahan yang bersifat progresif, terarah, dan terpadu. Progresif mengandung arti bahwa perubahan yang terjadi mempunyai arah tertentu dan cenderung maju kedepan, tidak mundur ke belakang. Terarah dan terpadu menunjukkan bahwa terdapat hubungan yang pasti antara perubahan yang terjadi pada saat ini, sebelumnya dan berikutnya. Masa kritis perkembangan anak perlu mendapatkan perhatian. Kebutuhan dasar anak untuk tumbuh dan berkembang salah satunya adalah kebutuhan fisik-biomedis dimana dalam kebutuhan ini pangan/gizi merupakan kebutuhan terpenting, (Soetjiningsih dan Ranuh, 2014)

Pada perkembangan anak, ada 4 (empat) aspek yang harus dipantau, yaitu: fisik motorik, kognitif, bahasa/bicara, dan sosialemosional. Setiap anak memiliki tonggak-tonggak perkembangan sesuai tahap usianya, artinya pada rentang usia tertentu, diharapkan seorang anak memiliki kemampuan tertentu. Misal, usia 8-9 bulan dapat duduk sendiri atau dapat berjalan di usia 12-13 bulan dan lainnya. Namun yang perlu diingat, tiap anak adalah unik. Untuk tiap anak, ada area-area dimana dia lebih tertinggal. Ada pula peran budaya dimana area perkembangan tertentu lebih di-reinforce kemunculannya. Misal, anak laki-laki yang penguasaan motorik kasar (memanjat, melompat, dan lainnya) dapat lebih cepat dibandingkan anak perempuan karena mendapat reinforcement. Walaupun beberapa ketertinggalan bersifat wajar, tetapi orangtua harus waspada bila keterlambatan ini meliputi berbagai area. (Kurniasih, et al., 2008)

Perkembangan anak harus dioptimalkan agar dapat mencapai kondisi yang baik di masa yang akan datang. Stimulasi perkembangan menjadi hal yang sangat penting bagi perkembangan anak. (Nugroho 2009) Selain adanya stimulasi perkembangan juga dipengaruhi oleh faktor-faktor diantaranya, yaitu genetik, saraf, hormon, status gizi, kecenderungan sekuler, status sosial ekonomi, cuaca dan iklim, tingkat aktivitas, penyakit dan cacat lahir. (Proverawati dan Wati, 2011) Desa Sirnoboyo merupakan desa yang terletak di Kabupaten Wonogiri. 
Dilihat dari data yang diperoleh yaitu hasil wawancara dengan bidan dan masyarakat sekitar, terdapat sekitar 35 anak usia 1-5 tahun (Balita) di desa Sirnoboyo. Anak - anak tersebut mempunyai pola dan irama pertumbuhan dan perkembangan sendiri-sendiri. Dari informasi masyarakat di Desa Sirnoboyo ada beberapa anak yang seharusnya di usianya sudah mampu berjalan tetapi belum mampu berjalan, dan informasi dari kader posyandu masih ada anak - anak yang berat badannya kurang (tidak sesuai dengan usia) sebagian besar dari ibu balita rutin datang ke posyandu setiap bulan untuk menimbang berat badan, namun penilaian perkembangan belum pernah dilakukan pada balita. Fokus perhatian orang tua biasanya hanya pada penilaian pertumbuhan bukan perkembangan anak. Berdasarkan latar belakang di atas peneliti tertarik melakukan penelitian tentang "Hubungan Status Gizi dengan Perkembangan Anak Usia 1-5 Tahun di Posyandu Desa Sirnoboyo Kabupaten Wonogiri".

\section{TUJUAN PENELITIAN}

1. Tujuan Umum

Untuk mengetahui hubungan status gizi dengan perkembangan Anak Usia 1-5 Tahun di Posyandu Desa Sirnoboyo Kabupaten Wonogiri.

2. Tujuan Khusus
a. Mengidentifikasi status gizi anak usia 1-5 tahun di Posyandu Desa Sirnoboyo Kabupaten Wonogiri.
b. Mengidentifikasi perkembangan anak usia 1-5 tahun di Posyandu Desa Sirnoboyo Wonogiri
c. Menganalisa hubungan status gizi dengan perkembangan anak usia $1-5$ tahun di Posyandu Desa Sirnoboyo Wonogiri.

\section{METODE PENELITIAN}

Penelitian ini merupakan penelitian korelasi dengan pendekatan cross sectional untuk mengetahui hubungan antara status gizi dengan perkembangan anak usia $1-5$ tahun di posyandu Desa Sirnoboyo Wonogiri. Dalam penelitian ini peneliti menggunakan teknik purposive sampling dengan sampel penelitian adalah 35 anak usia $1-5$ tahun beserta dengan ibunya..

\section{HASIL PENELITIAN}

Berdasarkan penelitian yang telah dilakukan didapatkan karakteristik responden berdasarkan umur, jenis kelamin dan pengasuh anak beserta hasil penelitian mengenai hubungan status gizi dengan perkembangan anak usia 1 - 5 tahun di posyandu Desa Sirnoboyo Wonogiri, yaitu sebagai berikut :

Tabel 1

Distribusi Frekuensi Status Gizi Anak

\begin{tabular}{ccc}
\hline Status Gizi & $\mathrm{f}$ & $\%$ \\
\hline Kurang & 9 & 25,71 \\
\hline Baik & 25 & 71,43 \\
\hline Lebih & 1 & 2,86 \\
\hline Jumlah & 35 & 100 \\
\hline
\end{tabular}

Dari data di atas dapat dicermati bahwa jumlah responden paling banyak adalah responden dengan status gizi baik yaitu sebanyak 25 anak $(71,43 \%)$ dan jumlah paling sedikit adalah anak dengan status gizi lebih yaitu 1 anak (2,86 \%).

Tabel 2

Distribusi Frekuensi Perkembangan Anak

\begin{tabular}{ccc}
\hline Perkembangan & f & $\%$ \\
\hline Normal & 24 & 68,57 \\
\hline Questionable & 11 & 31,43 \\
\hline Jumlah & 35 & 100 \\
\hline
\end{tabular}

Dari tabel di atas dapat dapat dicermati bahwa dari 35 anak, yang memiliki perkembangan normal sebanyak 24 anak (68,57\%) dan 
Questionable sebanyak 11 anak $(31,43 \%)$.

Tabel 3

Analisa Bivariat Hubungan Status Gizi Dengan Perkembangan

\begin{tabular}{cccc}
\hline Perkembangan & Normal & $\begin{array}{c}\text { Ques } \\
\text { tionable }\end{array}$ & Total \\
\hline Baik & 21 & 4 & 25 \\
\hline Kurang & 3 & 6 & 9 \\
\hline Lebih & 0 & 1 & 1 \\
\hline Total & 24 & 11 & 35
\end{tabular}

Dari tabel di atas dapat dianalisa bahwa :

1 Jumlah anak yang memiliki status gizi baik sebanyak 25 anak, dari jumlah tersebut 21 anak (60\%) dengan perkembangan yang normal dan 4 anak $(11,4 \%)$ dengan perkembangan questionable / meragukan.

2 Jumlah anak yang memiliki status gizi kurang sebanyak 9 anak, dari jumlah tersebut 3 anak $(8,6 \%)$ dengan perkembangan normal dan 6 anak $(17,1 \%)$ dengan perkem bangan questionable.

3 Anak yang memiliki status gizi lebih dan perkembangan questionable 1 anak (2,9\%)

Dari hasil uji Chi-Square program SPSS versi 18.0 dengan $\alpha=5 \%$ $(0,05)$ diperoleh $p$-value sebesar 0,006 dengan nilai koefisien kontingensi sebesar 0,474. Dari hasil tersebut menunjukkan nilai $p<0,05$ yang berarti $\mathrm{Ho}$ ditolak dan $\mathrm{H}_{\mathrm{a}}$ diterima sehingga ada hubungan positif dan signifikan dengan tingkat korelasi sedang antara status gizi dengan perkembangan anak usia 1 - 5 tahun di posyandu Desa Sirnoboyo Kabupaten Wonogiri.

\section{PEMBAHASAN}

Status Gizi

Status gizi merupakan keadaan kesehatan yang ditentukan oleh nutrien yang diterima dan dimanfaatkan oleh tubuh. (Hartono, 2006) Status gizi balita diukur berdasarkan umur, berat badan (BB) dan tinggi badan (TB). Salah satu penilaian status gizi berdasarkan indikator antropometri berat badan menurut umur $(\mathrm{BB} / \mathrm{U})$, dimana untuk menilai status gizi anak, maka angka berat badan dikonversikan ke dalam bentuk nilai terstandar (Z-score) dengan menggunakan baku antropometri WHO 2005. Selanjutnya berdasarkan nilai ZScore ditentukan kategori status gizi anak yaitu kategori gizi buruk jika Zscore $<-3$, kategori gizi kurang jika Z-score $>=-3 \mathrm{~s} / \mathrm{d}$ Z-score $<-2$, kategori gizi baik jika Z-score $>=-2$ s/d Z-score $<=2$ dan kategori gizi lebih jika Z-score $>+2$. Berdasarkan tabel 4.4 menunjukkan anak dengan status gizi baik sebanyak 25 anak $(71,43 \%)$, dengan status gizi kurang sebanyak 9 anak $(25,71 \%)$ dan anak dengan status gizi lebih sebanyak 1 anak (2,86\%). Dari data tersebut dapat diketahui bahwa sebagian besar anak memiliki status gizi baik.

Ada beberapa faktor yang bisa mempengaruhi status gizi pada anak diantaranya adalah asupan makanan, penyakit infeksi, dan pola pengasuhan anak. Anak yang mendapat makanan yang cukup baik tetapi sering diserang penyakit infeksi dapat berpengaruh terhadap status gizinya. Begitu juga sebaliknya anak yang makannya tidak cukup baik, daya tahan tubuhnya pasti lemah dan pada akhirnya mempengaruhi status gizinya. Pola pengasuhan anak, berupa sikap dan perilaku ibu atau pengasuh lain dalam hal keterdekatannya dengan anak, memberikan makan, merawat, 
kebersihan, memberi kasih sayang dan sebagainya.

Salah satu faktor yang mempengaruhi status gizi adalah penyakit infeksi. Berdasarkan data pada penelitian ini, responden dalam penelitian adalah anak yang tidak mempunyai riwayat penyakit kronis dan tidak sedang sakit atau dalam keadaan sehat pada saat dilakukan penelitian. Jika kondisi anak selalu sehat dan asupan makanan tercukupi maka status gizi anak akan berada dalam keadaan baik.

Faktor lain yang berpengaruh pada status gizi adalah pola pengasuhan anak. Dalam penelitian ini sebagian besar anak di asuh oleh orang tua sendiri yaitu sebanyak 27 anak ( $77,14 \%$ ) dan hanya 8 anak $(22,86 \%)$ yang di asuh oleh nenek serta tidak ada anak yang diasuh oleh pengasuh. Dengan pengasuhan yang dilakukan oleh orangtua khususnya ibu sendiri dan bukan oleh pengasuh atau nenek, dimana orangtua biasanya lebih memiliki keterdekatan dengan anak, memiliki tanggung jawab dalam merawat anak, memenuhi kebutuhan makan dan memberikan kasih sayang serta perhatian pada anak, hal ini akan membantu terpenuhinya kebutuhan gizi bagi anak. Seperti penelitian yang dilakukan oleh Rapar, Rompas, dan Ismanto (2014) dimana hasil penelitian menunjukkan ada hubungan antara pola asuh ibu dengan status gizi balita. Kondisi ini didukung dengan ibu yang memiliki lebih banyak waktu di rumah, hal ini bisa dilihat dari pekerjaan ibu sebagian besar membantu suami sebagai petani $(77,1 \%)$ sehingga ibu bisa memiliki cukup waktu untuk merawat anak di rumah termasuk dalam memberikan makan bagi anak dan ibu juga memiliki waktu untuk membawa anaknya ke posyandu, hal ini bisa dilihat dari KMS yang dimiliki oleh setiap anak dan dari data posyandu sebagian besar ibu selalu rutin membawa anaknya ke posyandu. Dengan mengikuti posyandu dan memiliki KMS (Kartu Menuju Sehat) maka pertumbuhan atau status gizi anak dapat terpantau setiap bulan. Dari data di atas menunjukkan adanya beberapa faktor yang mendukung sehingga anak usia 1 - 5 tahun di desa Sirnoboyo sebagian besar memiliki status gizi yang baik.

\section{Perkembangan Anak}

Perkembangan adalah bertambah nya kemampuan (skill) struktur dan fungsi tubuh yang lebih kompleks, dalam pola yang teratur dan dapat diramalkan, sebagai hasil dari proses pematangan. (Soetjiningsih dan Ranuh, 2014) Salah satu alat untuk melakukan pengukuran terhadap perkembangan anak adalah dengan menggunakan MMDST dimana interpretasi hasil pengukuran di kategorikan dalam kategori normal, questionable (meragukan), abnormal, dan untestable.

Hasil penelitian yang telah dilakukan menunjukkan bahwa perkembangan anak usia 1 - 5 tahun di Posyandu Desa Sirnoboyo Kabupaten Wonogiri sebagian besar adalah normal yaitu sebanyak 24 anak $(68,57 \%)$ dan perkembangan questionable sebanyak 11 anak $(31,43 \%)$. Dari penelitian tidak didapatkan anak dengan perkembangan abnormal dan seluruh anak bersedia untuk melakukan tes yang diberikan sehingga tidak ada untestable.

Faktor yang mempengaruhi perkembangan anak diantaranya adalah keadaan kesehatan kronis, ketahanan pangan keluarga, pola asuh anak, pemanfaatan palayanan kesehatan dan sanitasi lingkungan. (Soetjiningsih dan Ranuh, 2014) 
Responden dalam penelitian ini adalah anak usia 1 - 5 tahun yang tidak memiliki riwayat penyakit kronis yaitu penyakit yang membutuhkan perawatan terus menerus termasuk kelainan perkembangan seperti autis, serebral palsi, dan sebagainya. Pada saat dilakukan penelitian seluruh anak sedang dalam keadaan sehat. Anak dengan kondisi kesehatan kronis yang tidak baik sering mengalami gangguan tumbuh kembang, sedangkan seluruh responden dalam keadaan kesehatan kronis yang baik, hal ini yang memungkinkan sebagian besar responden memiliki perkembangan yang normal. Demikian juga keluarga telah memanfaatkan pelayanan kesehatan yang ada seperti posyandu. Dengan membawa ke posyandu secara teratur maka secara rutin bisa dilakukan pemantauan kesehatan dan pertumbuhannya serta bisa dilakukan deteksi secara dini adanya gangguan tumbuh kembang pada anak.

Soetjiningsih dan Ranuh (2014) mengatakan bahwa pola pengasuhan merupakan faktor yang juga mempengaruhi perkembangan anak. Anak yang diasuh oleh orang tua sendiri akan menciptakan interaksi antar anak dan orang tua sehingga dapat membangun keakraban dalam keluarga yang merupakan lingkungan kondusif yang dapat mempengaruhi perkembangan fisik dan mental yang baik bagi anak. Berdasarkan hasil penelitian ini didapatkan sebagian besar anak diasuh oleh orang tua sendiri yaitu $77,14 \%$, dari analisa peneliti, anak yang diasuh oleh orangtua sendiri akan memiliki waktu yang cukup banyak untuk berinteraksi dengan ayah dan ibu mereka, hal ini memungkinkan orang tua lebih mudah untuk memberikan stimulasi yang maksimal sehingga perkembangan anak bisa optimal, seperti hasil penelitian yang menunjukkan sebagian besar responden memiliki perkembangan yang normal. Namun dalam penelitian ini peneliti tidak melakukan penelitian mengenai stimulasi dalam membantu perkembangan sehingga tidak diketahui seberapa besar pengaruh stimulasi terhadap perkembangan anak dan untuk itu perlu dilakukan penelitian tersendiri.

Dalam penelitian ini masih di jumpai sebagian anak (31,43\%) dengan perkembangan questionable / meragukan. Apabila perkembangan anak meragukan maka perlu dilakukan uji ulang dalam $1-2$ minggu untuk menghilangkan faktor sesaat seperti rasa takut, keadaan sakit atau kelelahan, namun tes tersebut tidak dilakukan oleh peneliti, hal tersebut merupakan keterbatasan dari penelitian ini.

Hubungan Status Gizi dan Perkembangan anak

Dari hasil uji Chi-Square program SPSS versi 18.0 dengan $\alpha=5 \%$ $(0,05)$ diperoleh $p$-value sebesar 0,006 dengan nilai koefisien kontingensi sebesar 0,474. Dari hasil tersebut menunjukkan nilai $p<0,05$ yang berarti $\mathrm{Ho}$ ditolak dan $\mathrm{H}_{\mathrm{a}}$ diterima sehingga ada hubungan positif dan signifikan dengan tingkat korelasi sedang antara status gizi dengan perkembangan anak usia 1 - 5 tahun di posyandu Desa Sirnoboyo Kabupaten Wonogiri.

Gizi menjadi bagian yang sangat penting dalam pertumbuhan dan perkembangan. Hal ini seperti di ungkapkan oleh Proverawati dan Wati (2011), bahwa salah satu faktor yang mempengaruhi tumbuh kembang anak adalah faktor biologis dimana salah satunya adalah gizi. 
Status gizi pada masa balita (bawah lima tahun) perlu mendapatkan perhatian yang serius dari orang tua, karena kekurangan gizi pada masa ini akan menyebabkan kerusakan yang irreversibel dan bisa berdampak pada perkembangan otak. (Proverawati dan Wati, 2011) Pertumbuhan jaringan otak yang pesat pada anak terjadi pada usia bayi sampai dengan 2 tahun. Pada usia 2 tahun ukuran otak anak mencapai $80 \%$ dari ukuran otak orang dewasa. Selanjutnya otak akan terus berkembang dengan perkembangan yang lebih lambat. Otak yang tidak berkembang secara optimal maka akan mempengaruhi perkembangan kognitif dari anak. Perkembangan kognitif meliputi kemampuan anak memahami dunianya melalui inderanya, kecakapan motorik dan proses berfikir baik logis maupun abstrak. Diperlukan asupan nutrisi yang baik pada masa pertumbuhan dan perkembangan otak agar otak dapat berkembang secara optimal, sehingga anak memiliki perkembangan kognitif yang optimal. (Soetjiningsih dan Ranuh, 2014)

Skrining dan pemantauan terhadap perkembangan anak dilakukan dengan instrumen skrining perkembangan salah satunya menggunakan MMDST yang meliputi empat aspek yaitu motorik (motorik halus dan motorik kasar), personal - sosial, dan bahasa.

Pada penelitian yang dilakukan terhadap anak usia $1-5$ tahun di posyandu Desa Sirnoboyo di peroleh hasil pada anak yang memiliki status gizi baik sebagian besar (60\%) memiliki perkembangan yang baik, dan pada anak yang memiliki status gizi kurang sebagian besar $(17,1 \%)$ memiliki perkembangan questionable/meragukan. Dari hasil tersebut menunjukkan anak yang memiliki status gizi yang baik perkembangannya juga cenderung baik. Hal ini sangat dimungkinkan oleh karena status gizi yang baik menunjukkan zat - zat gizi yang dibutuhkan untuk tubuh/jaringan supaya bisa berfungsi, tumbuh dan berkembang sudah terpenuhi, dan seperti yang telah diuraikan sebelumnya bahwa salah satu faktor yang mempengaruhi perkembangan anak adalah faktor nutrisi atau gizi, karena zat gizi yang meliputi taurin dibutuhkan untuk perkembangan otak, zat besi dibutuhkan untuk menghasilkan hemoglobin yang mencegah terjadinya anemia defisiensi. Zat besi penting untuk pertumbuhan dan perkembangan kognitif, protein yang cukup akan memelihara sel dan jaringan tubuh, kecukupan kalsium, fosfor dan komponen anorganik lain mempengaruhi pertumbuhan tulang, berbagai vitamin diperlukan untuk proses metabolisme dan pertumbuhan yang normal, demikian juga iodium merupakan mikronutrien yang penting untuk pertumbuhan otak anak.

Hasil penelitian ini yang menunjukkan adanya hubungan antara status gizi dengan perkembangan anak usia $1-5$ tahun di posyandu Desa Sirnoboyo juga telah dibuktikan oleh Lindawati (2013), pada penelitiannya yang berjudul "Faktor - faktor yang berhubungan dengan perkembangan motorik anak usia pra sekolah di PAUD wilayah Kecamatan Cilandak Jakarta Selatan". Hasil penelitian menunjukkan variabel yang paling berhubungan dengan perkembangan motorik anak usia prasekolah adalah variabel status gizi. Dan penelitian yang dilakukan oleh Zulaikhah (2010), pada penelitiannya yang berjudul "Hubungan Status Gizi dengan Perkembangan Anak Usia 2 sampai 3 Tahun di Wilayah Kerja 
Puskesmas Gambirsari Kota

Surakarta. Hasil penelitian menunjukkan terdapat hubungan positif dan signifikan antara status gizi dengan perkembangan anak usia 2 sampai 3 tahun di Wilayah Kerja Puskesmas Gambirsari Kota Surakarta

Demikian juga pada responden dalam penelitian ini, dengan status gizi yang baik maka memungkinkan responden memiliki perkembangan yang baik juga. Namun dalam penelitian ini tidak semua responden yang memiliki status gizi yang baik juga memiliki perkembangan baik, masih ada sebagian anak dengan status gizi baik memiliki perkembangan yang questionable / meragukan, hal ini bisa terjadi karena terdapat faktor - faktor lain selain faktor gizi yang bisa mempengaruhi perkembangan anak seperti ketahanan pangan keluarga, stimulasi, pemanfaatan palayanan kesehatan dan sanitasi lingkungan. Faktor - faktor tersebut tidak dibahas dalam penelitian ini sehingga diperlukan penelitian lebih lanjut untuk faktor - faktor tersebut.

\section{KESIMPULAN}

1. Anak yang memiliki status gizi baik sebanyak 25 anak $(71,43 \%)$, kurang sebanyak 9 anak (25,71\%), dan lebih sebanyak 1 anak (2,86\%)

2. Anak yang memiliki perkembangan normal sebanyak 24 anak $(68,57 \%)$ dan perkembangan questionable/ meragukan sebanyak 11 anak $(31,43 \%)$

3. Hasil uji Chi-Square program SPSS versi 18.0 dengan $\alpha=5 \%$ (0.05) diperoleh $p$ sebesar 0,006 sehingga nilai $p<0,05$, yang berarti $\mathrm{Ho}$ ditolak dan $\mathrm{H}_{\mathrm{a}}$ diterima sehingga ada hubungan antara status gizi dengan perkembangan anak usia 1 - 5 tahun di Posyandu
Desa Sirnoboyo Kabupaten Wonogiri.

\section{SARAN}

1. Bagi tenaga kesehatan Diharapkan lebih meningkat kan lagi pemantauan terhadap status gizi anak dan melakukan secara rutin deteksi dini terhadap penyimpangan perkembangan anak.

2. Bagi orang tua diharapkan lebih meningkatkan wawasan tentang kebutuhan zat gizi pada anak dan perkembangan anak, sehingga orang tua dapat menerapkan pola asuh yang lebih baik dan menjamin tumbuh kembang anak berlangsung dengan selaras baik dari segi fisik, mental maupun psikososial.

3. Bagi Peneliti hasil penelitian ini diharapkan dapat digunakan sebagai dasar untuk penelitian selanjutnya yang berkaitan dengan ketahanan pangan keluarga, stimulasi, pemanfaatan palayanan kesehatan dan sanitasi lingkungan yang dihubungkan dengan perkembangan anak.

\section{DAFTAR PUSTAKA}

Adriana, Dian. 2011. Tumbuh Kembang dan Terapi Bermain pada Anak. Salemba Medika, Jakarta.

Hartono, Andri. 2006. Terapi Gizi dan Diet Rumah Sakit. Edisi II. EGC, Jakarta.

Hidayat, A. Aziz Alimul. 2009. Metode Penelitian Keperawatan Teknik Analisa Data. Salemba Medika, Jakarta.

2008. Riset Keperawatan dan Teknik Penulisan IImiah. Edisi II. Salemba Medika, Jakarta. 
Kurniasih, Dedeh, et al. 2008. Nakita Panduan Tumbuh Kembang Anak. PT. Penerbitan Sarana Bobo, Jakarta.

Muaris, Hindah. 2006. Bekal Sekolah Untuk Balita. PT. Gramedia Pustaka Utama, Jakarta.

Nugroho, Heru Santoso Wahito. 2009. Petunjuk Praktis Denver Developmental Screening Test: EGC, Jakarta.

Proverawati, Atikah dan Erna Kusuma Wati. 2011. IImu Gizi Keperawatan dan Gizi Kesehatan. Nuha Medika, Yogyakarta.

Soetjiningsih dan Gde Ranuh. 2014. Tumbuh Kembang Anak. Edisi II. EGC, Jakarta.

Sulistyawati, Ari. 2014. Deteksi Tumbuh Kembang Anak. Salemba Medika, Jakarta.

Sunarti, Euis. 2004. Mengasuh dengan Hati Tantangan yang Menyenangkan. PT. Elex Media Komputindo, Jakarta.

Williams, Phoebe Dauz. 2004. Penuntut Uji Skrening Perkembangan Anak menggunakan Metro Manila Developmental Screening Test. Alih Bahasa Yuliana Hanaratri. Mario Carlo Publishing, Tangerang.

World Health Organization. 2008. Buku Saku Pelayanan Kesehatan Anak di Rumah Sakit Pedoman bagi Rumah Sakit Rujukan Tingkat Pertama di Kabupaten/Kota. Alih Bahasa Tim Adaptasi Indonesia. WHO Indonesia, Jakarta.
Kumalasari, Dewi Anindita. 2013. "Hubungan antara Status Gizi dengan Perkembangan Anak Usia Toddler (1-3 Tahun) di Wilayah Kerja Puskesmas Wiradesa Kabupaten Pekalongan". URL: http://eprints.undip.ac.id/13736 /. Diakses 27 Juli 2015.

Rapar, Vicka Lourine, Sefti Rompas, dan Amatus Yudi Ismanto. 2014. "Hubungan Pola Asuh Ibu Dengan Status Gizi Balita di Wilayah Kerja Puskesmas Ranotana Weru Kecamatan Wanea Kota Manado". URL: http://ejournal.

Unsrat.ac.id/jkp/article/view/. Diakses 25 Februari 2016.

Salsabila. 2010. "Hubungan Status Gizi dengan Perkembangan Anak Usia 0-3 Tahun" http://skripsi-qt.blogspot .co.id/hubungan-status-gizidengan-perkembangan anak.html. Diakses 21 Mei 2015.

Sugiyono. 2003. Statistika Untuk Penelitian. CV. Alfa Beta, Bandung.

Zulaikah, Siti. 2010. Hubungan Status Gizi dengan Perkembangan Anak Usia 2 Sampai 3 Tahun Di Wilayah Kerja Puskesmas Gambirsari Kota Surakarta". URL:http://eprints.uns.ac.id/62 13/. Diakses 12 Juni 2015.

1 Dosen AKPER Panti Kosala Surakarta

2 Mahasiswa AKPER Panti Kosala Surakarta 